\title{
An attempt to explore the Interrelationship amongst various challenges faced by new and existing Talents in Art and Music in India
}

\author{
Aatif Sundke \\ MIT School of Education and \\ Research, MIT Art, Design and \\ Technological University \\ Pune, India
}

\author{
Remica Aggarwal \\ MIT School of Education and \\ Research, MIT Art, Design and \\ Technological University \\ Pune, India
}

\author{
V. K. Aggarwal \\ Recventures Education \\ Services Private Limited, India
}

\begin{abstract}
Present research work reviews the challenges faced by new and existing talents in India. The research work explores three categories of industry Art, craft and music. Hence, discusses the various barriers or challenges faced by the existing and buddings talents in these sectors. After the wide exploration, it tries to establish the interrelationship amongst them using ISM methodology .
\end{abstract}

\section{Keywords}

Artists , Musicians , Interpretive Structural Modeling Methodology, MIC -Mac Analysis , Budding talents

\section{INTRODUCTION}

It has been established now that a public- private partnership is mandatory for the upliftment of rejuvenating India through Art \& Culture . Today, the Indian cities are recognizing and encouraging its residents' unique cultural and societal habits and their visible identities. These efforts are further supported by Government's schemes and programs as mentioned below

- The Ministry of Culture is responsible for preservation, development and promotion of arts, culture, and heritage (tangible and intangible) in the country. Ministry is continuing to nurture mature art forms such as theatre, arts and literature in the present scenario of digitization and cinema through its support of institutions such as the National School of Drama, Sahitya Akademi and Sangeet Natak Akademi .

- As per UNESCO direction, the Ministry is also responsible for organising Indian festivals abroad .

- The Ministry of Culture has also initiated the National Mission on Cultural Mapping and Roadmap, which focuses on promoting 'Our Culture Our Identity' through media and events. The mission aims to target 6.40 lakh villages in 3 years and adopts a web-based integrated approach.

Music, being one of the indivisible aspects of society, it cannot devoid itself from the changing realities of the time. The listeners and artists, young and old are required to portray the Hindu scriptures and bhakti movements in a fresh and engaging way. After independence, Indian classical musicians had to struggle for their bread along with the responsibility of carrying forward their lineage of the tradition. However, with the changing socio-economic realities, the influence of Indian classical music in the west, the emerging critical voices amongst contemporary Indian students, the new conditions and contexts have led to many challenges faced by the musicians.

The rapid technological up-gradation in last two decades has given a new shape to the music in India . Technological innovations have certainly influenced classical music and have resulted in creating virtual classes ; online availability of music and musical instruments and their digitization. We of course had some phenomenal musicians performing worldwide enthralling audiences. However, Indian classical musicians always have had difficulty in establishing and making an impact worldwide. Some basic considerations while choosing Indian classical musicians to perform internationally includes the number of musical performances to their credit ; generation of funds by the performer; popularity and fame of artist in India and abroad and acceptance of music form which isn't very popularly known.

While giving the live or studio performances, the artists as well as musicians already had proved their calibre and have adapted to the pressure of performing on stage . And that's great - playing music live is hard work and you should always look to develop this aspect of your music career. When it comes down to recording music in the studio, artists and bands need to adopt an approach distinct from that adopted on-stage.The focus here isn't about the top elite wellestablished artists, but about the budding upcoming artistes who struggle to get a firm footing.

The present research focuses on exploring various types of challenges which are faced by new and existing artists and musicians in India. In section 2 , these challenges have been explained. Thereafter section 3 describes the ISM methodology. Managerial implications have been presented in section 4 .

\section{LITERATURE REVIEW ON CHALLENGES FACED BY INDIAN ARTISTS AND MUSICIANS}

\subsection{An exploration of various challenges faced by art and culture sector}

To truly unleash the potential of the Indian Art and Culture sector, it is imperative to gain a holistic understanding of the economic landscape of the country including the current challenges. Below are discussion of the overarching challenges faced by Indian Art and Culture sector in urban landscape.

1 Policy support for developing cultural infrastructure (PSCI): The Indian art and culture landscape is rich in cultural capital but significantly lacks in building and 
maintaining cultural infrastructure. Country lacks in developing a comprehensive policy which focuses on the entire cultural ecosystem, from protecting, preserving and promoting art to creating cultural spaces which can house new cultural assets. As an example, Sydney has adopted a policy in 2012 for creating cultural infrastructure where spaces for professional creatives and art-forms shall be practiced. One of the direct outcome was the creation of creative hub which is a residential accommodation for artists and their artwork.

2. Declining use of art in cities (DUA): Gradually, the use of art and culture in Indian cities is fading away with contemporary development agenda. Urban art is intrinsic to create quality public spaces. With rapidly changing urban development scenarios, Master Plans, City development policies and building bye-laws are yet to accommodate urban art in their directives. An inspirational example is Bogota, which has identified 'Graffiti' as an urban cultural practice and developed a policy aiming at building a city which recognizes 'Graffiti' and promote improvement of streetscapes with street art along with promoting graffiti artists.

3. Lack of integrated approach for building city identity (LIA) : In present economic landscape, Indian cities are facing challenges to balance the traditional city culture and modernization due to which the uniqueness of the cities is diluting. Major factors behind this are lack of integrated approach as well as limited role of public private partnership in city building . Paris has built a 'City for Art' brand through art-centric policy. It has formulated a policy which supports cultural diversity and provide framework for sustainable employment of artists and support their art work. Affordable workspaces for artists and developing art and cultural hubs across the city has led to uphold the global brand city for art.

4. Insufficient funding and low utilisation (IFLU) : Art and culture is never part of the mainstream. Government bodies across the world don't include art and culture industry on their priority list when it comes to budget allocation. Budget allocated to Art \& Culture has grown in absolute numbers over the years, benefiting from India's growing economy but relatively its allocation remains well under $1 \%$ of the total annual budget. A closer observation of the budget and expenditure in financial year 2016-17 reveals that funds allocated were INR 25 billion whereas spent were just INR 17.2 billion; $31 \%$ of funds were unutilized.

5. Institutional constraints to upskill artists ( ICUA) : Artists form the foundation of a city's creative environment. They act as creators, teachers, and individual entrepreneurs who provide many of the products and designs that drive innovation and shape a city's cultural identity. The current state of government funding for artists is abysmally low, driving them to pursue their careers under economic hardships forcing them to bear the burden of creating, promoting and selling pieces of art. Also, artists face real challenges in upskilling themselves due to lack of institutional training and development activities.

6. Low potential to attract private investment (LPPI): Due to limited stakeholders in art and culture sector and low revenue earning potential, art based projects in cities find it difficult to get private investment through Public-Private partnership. Moreover, such projects should aim at enhancing innovation and creativity from private partner's collaboration and never be judged on low bid criteria.
7. Art forgery (AF) : Art and culture industry remains largely unregulated due to unavailability of standard regulating mechanism. Numerous stakeholders are working in the market space independently. Thus, efforts are highly decentralized resulting in underutilized capacity. This makes the art \& culture industry highly prone to forgeries. Along with this, there is lack of transparency with respect to art trade market which may further lead to money laundering and forgery.

\subsection{Challenges faced by budding or upcoming classical as well as contemporary musicians ${ }^{[1-13]}$ :}

Musicians are not necessarily influenced by the music that they recite but also have to look after various other factors such as :

1. Shortage of funds (SOF) : Touring is extremely expensive. Add on to it the exchange rates, living costs and travel costs.

2. Marketing and launching oneself $(\mathbf{M} \& \mathbf{L})$ : is very important to maintain a position in the international market. Just being an excellent musician is not enough in this commercial world.

3. Strict cultural package (SCP) : Indian Classical music comes with a strict cultural package - No playing in bars, No street music. As the taboo is very strong any dramatic attempt will surely have a long-term negative impact.

4. Language (LAN) : Though there is a popular proverb that "Music doesn't have any language barrier", but the impact of lyrical meaning is completely lost.

5. Adjustments in performance patterns (APP) : This includes travelling halfway across the globe for a few minutes of performance. In addition , it is expected that artists should make their performances worth listening maintaining both the technicality with the emotional or aesthetic facet in a very little span of time.

6. Cost concerns (CC): While there is an attempt to provide specific solutions to most issues, costs continue to be a key concern to many Indian musicians trying to establish themselves in an international circuit. To perform at the bigger festivals abroad, the musicians need to go through agents.

7. Lack of formal contracts (LFC): Younger artists cannot afford to have agents who act as a commission middleman between the organizer and an artist. Often, organizers would vanish after performances, without paying dues or clearing hotel and travel bills due to lack of formal contracts .

8. Overseas tours (OT): This still remain an adventure for Indian classical musicians, though there have been some changes for the better. For example, you cannot get a visa to perform in some countries without proving that you have adequate insurance cover. In addition, there is a need to professionalize other terms and conditions such as work hours, hospitality and accommodation, payment schedules, contracts and agreements. 


\subsubsection{Additional challenges faced by artists/ musicians while performing live and / or giving studio performances [ 14-23]}

10. Challenge to deliver an authentic and expressive performance (A\&EP): Though the artists carry a lot of name and fame required to perform in a live performance, still it is very much expected that given live show is an immediate experience, you have to carry on with performance and maintain the craze of audience. When you're performing your music, many minute music details often get swallowed up by acoustics and volume. Audience can let go if there are quality compromise over strings, missed notes or failed equipment because they are not attending the live show to hear the best quality song. They have already heard it over the musical CDs, they are interested and paying to meet and see their favourite star performing in real right in front of them. Star performance therefore has to be authentic and expressive as possible.

11. Economic budget (EB): While performing studio recordings, the artists and musicians are already working on an economic budget and missing crowd so here quality recording of music and minimal imperfections is the goal. Recording sessions do involves tweaks, breaks, replays and often interruptions before settling down to final song. A single track may take hours and several attempts to catch up the highest quality. Studio recordings give musicians the opportunity to capture these subtle moments - each packed with expression and emotion - in all their glory.

\section{MANAGERIAL IMPLICATIONS \& CONCLUSIONS}

- Recording locally and releasing via social media. This not only reduces the cost and an effort, but the technology also makes budding artists to market and launch themselves to a wider audience.

- For marketing, the musicians need an advertisement. Almost every musician of today has an official website with their musical profile, audio/video. They are actively being followed on Facebook, Instagram, YouTube and other social network mediums.

- The musician has to adapt and invent outside Hindu mythology to move to subjects of nature. Ex:- five elements of nature, mothers love, health or socioeconomic issues

- Group performances and Jugalbandhis. These increases the chances, optimizes the costs and also provides larger exposure to the musicians. Rendering lecture demonstrations in between a long concert is always an effective way of engaging the audience.

\section{FUTURE DIRECTIONS}

- ISM methodology proposed by Warfield [24] can be used further to establish the relationship amongst the various barriers .

- Further in addition to ISM methodology, other techniques such as AHP, DEMATEL , Fuzzy DEMATEL etc. can be also used .

\section{ACKNOWLEDGMENTS}

The given piece of work is a tribute to the finest talents being produced by Faculty of Music and Fine Arts, Delhi, India ; Department of Music, BITS Pilani and Coke Studio, Pakistan. Author Remica Aggarwal extend her warm regards to the faculties and students of National School of Drama, Delhi for the motivation to write this piece of research.

\section{REFERENCES}

[1] https://www.classicalclaps.com/challenges-and-waysahead-for-indian-classical-musicians-to-go-international/

[2] https://www.pwc.in/assets/pdfs/publications/2018/transfo rming-urban-india.pdf

[3] https://en.unesco.org/creativity/sites/creativity/files/cultu ral_times._the_first_global_map_of_cultural_and_creative_industries.pdf

[4] https://whc.unesco.org/en/statesparties/in

[5] https://www.hindustantimes.com/real-estate/why-smartcities-need-art-and-culture-to-thrive/story-axqPb391LEDv31OHDZDFNN.html

[6] http://www.worldcitiescultureforum.com

[7] https://indiaculture.nic.in/sites/default/files/annualreports/AnnualReportMOCEnglish_20172018_25.05.2018.pdf

[8] https://timesofindia.indiatimes.com/travel/destinations/th is-year-hara-ghoda-at-the-kala-ghoda-arts-festival2018/as62619407.cms

[9] https://www.livemint.com/Leisure/jatuIdIVDA8h3qlSPP x1DL/Art-out-on-the-streets.html

[10] https://www.smartcitybhubaneswar.gov.in/i-am-bbsr

[11] https://economictimes.indiatimes.com/industry/services/t ravel/kumbh-mela-2019-to-be-promoted-globally-toattract-foreign-tourists-kjalphons/articleshow/65107591.cms

[12] http://www.palpalindia.com/2018/11/19/jabalpur-mpStreet-Art-Festival-Beauty-City-Municipal-CorporationSmart-City-Company-Limited-news-in-hindi260022.html

[13] https://www.indianholiday.com/fairs-andfestivals/pondicherry/international-yoga-festival.html

[14] Lynch, K. 1960. The image of the City. Cambridge: Cambridge, Mass. : MIT Press. http://www.miguelangelmartinez.net/IMG/pdf/1960_Kevin_Lynch_The _Image_of_The_City_book.pdf

[15] Projectforpublicspace.2018.https://www.pps.org/article/ what-is-placemaking

[16] Nations, U. 2018. The World Cities in 2016 http://www.un.org/en/development/desa/population/publi cations/pdf/urbanization/the_worlds_cities_in_2016_data _booklet.pdf

[17] Gehl, J. 2017. Placemaking: The Public Realm's impact on value. Denmark. https://www.cbre.com/research-andreports/Global-Placemaking-Value-and-the-PublicRealm-May-2017 
[18] Wyckoff, M. A. 2014. Definition of placemaking : Four Different Types. MSU Land Policy Institute, 2-10. http://smartcities.gov.in/upload/development/59955bd81 aa1cPlace\%20making\%20guideline\%20Bhopal.pdf

[19] http://smartcities.gov.in/content/city_challenge.php?page =winning-city-proposals-in-round-3.php

[20] Mathew, A. 2011. Interactive Placemaking: Three critical enquiries into urban interaction in place. Chicago. http://papers.cumincad.org/data/works/att/acadia11_362. content.pd

[21] Watershed.2018.Vision.https://www.playablecity.com/vi sion/
[22] Wood, B. 2018. Team Lab launches the world's first digital art museum in Tokyo. The Spaces. https://thespaces.com/teamlab-launches-the-worlds-firstdigital-art-museum-in-tokyo/

[23] Partners, E. D. 2017. Place matters: The role of placemaking in Economic Development. Washington, DC: International Economic Development Council. http://www.bigskyeconomicdevelopment.org/wpcontent/uploads/EDRP_Placemaking.pdf

[24] Warfield, J. N. 1974. Developing interconnection matrices in structural modeling. IEEE Transactions on System, Man, and Cybernetics, SMC-4 (1), 81-87. 